\title{
Isolation of a Virus from a Sporadic Case of Izumi Fever
}

\author{
By
}

\author{
Masahiko Kuroya, Yoshiro Yoshinari, Nakao Ishida, \\ (黑屋政䓂) (吉成芳郎) (石田名香焳) \\ Ki-ichiro Noda and Eiji Koseki \\ （野田起一郎）（小關英治） \\ From the Departments of Bacteriology (Prof. M. Kuroya), \\ Pathology (Prof. S. Nasu), and Pediatrics (Prof. T. Sano), \\ Tohoku University, Sendai
}

(Received for publication, June 3, 1953)

"Izumi Fever" is one of the important exanthematic diseases in this country, which is confined almost to children and may occur either in a sporadic or in an endemic form. It is characterized by a transient fine rash resembling that of scarlatina and followed by some intestinal disorders.

Many authors have endeavoured to isolate the virus and to establish their causative nature, but almost all of them failed in volunteer experiments. We succeeded to produce a typical infection in an 8-years-old female by an oral administration of the isolated virus. After 4 days incubation period, saddleback type fever, bilateral exanthema of arms, angina and urobilinogen in urine were recognized and the study is now in progress to isolate the same virus from feces and blood of this child again.

The virus was isolated from a sporadic case by intracerebral inoculation of the Berkefeld filtrate of feces to young mice. Subsequently the virus was transferred from brain to brain and now fully adapted to mice. These mice usually dies until 5 days after inoculation and $\mathrm{LD}_{50}$ for mice weighing $8 \mathrm{~g}$. in average is $10^{-8.5}$. They are stored in $50 \%$ glycerol for a month without loss of activity. Histopathological changes in mice were more conspicuous at the begining of isolation of the virus in liver, spleen and kidney, but later chiefly focused in brain, causing encephalitis and leptomeningitis. Egg culture and purification of virus were performed, but succeeded not yet.

Neutralization antibody against this virus was proved in the serum of patient from whom the virus was isolated 3 and 4 month after onset. Complement fixation test was also performed. 